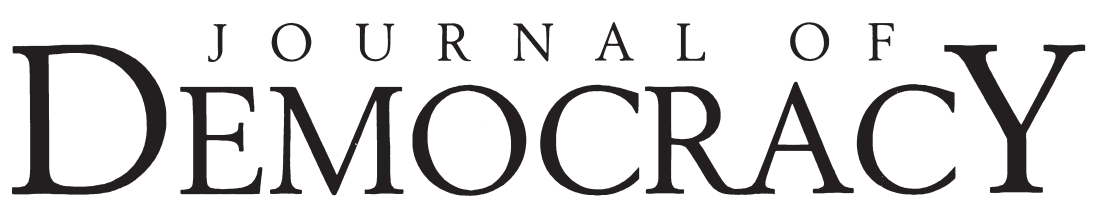

January 2018, Volume 29, Number $1 \$ 14.00$

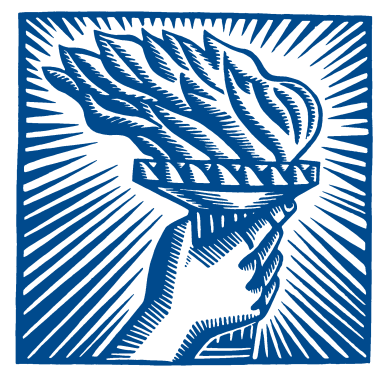

\title{
The Rise of Kleptocracy
}

Alexander Cooley, John Heathershaw, and J.C. Sharman - Oliver Bullough

Andrew Wedeman - Miriam Lanskoy and Dylan Myles-Primakoff

Christopher Walker and Melissa Aten - Brett Carter - Cynthia Gabriel

\section{Burma: Suu Kyi's Missteps \\ Zoltan Barany}

\section{Reevaluating Runoffs in Latin America}

Cynthia McClintock

Edward Aspinall et al. on Timor-Leste Ben Margulies vs. Takis Pappas on Nativism

Carl Gershman on Condoleezza Rice

\section{Terrorism and Democracy}

Amichai Magen - Geoffrey Macdonald and Luke Waggoner 


\title{
The Rise of Kleptocracy
}

\section{LAUNDERING CASH, WHITEWASHING REPUTATIONS}

\author{
Alexander Cooley, John Heathershaw, and J.C. Sharman
}

\begin{abstract}
Alexander Cooley is director of the Harriman Institute at Columbia University and Claire Tow Professor of Political Science at Barnard College. John Heathershaw is associate professor of international relations at the University of Exeter. J.C. Sharman is Sir Patrick Sheehy Professor of International Relations at the University of Cambridge.
\end{abstract}

Kleptocracy and grand corruption are now under scrutiny as never before. With renewed global attention on these abuses, a relatively clear picture has emerged of the domestic political economies shaped by kleptocratic rule. Analysts have shown how state institutions are set up to allow elites and their families to systematically loot, while protecting these elites politically. In particular, this research has placed under the microscope the resource-rich countries that are vulnerable to kleptocratic state capture.

Yet to understand the operations of today's jet-setting kleptocrats, one must look beyond the borders of the polities they despoil. Copious news items feature kleptocrats and their families purchasing luxurious penthouses and cars; attending international cultural galas and charitable initiatives; and enlisting Western agents, lawyers, spokespeople, and pillars of the establishment to whitewash their reputations. Watchdogs and policy makers are beginning to turn their attention to the wide range of kleptocratic activity that takes place in the West itself ${ }^{1}$ - whether this entails Equatorial Guinea's vice-president standing trial in France for corruption, the former president of Uzbekistan's daughter facing investigations for money laundering in a half-dozen countries, or the Malaysian prime minister under suspicion in connection with the diversion of more than US\$4.5 billion from his country's sovereign wealth fund into personal bank accounts around the world. Conceptual analysis explaining how these pieces fit together, however, remains scarce.

Kleptocrats do not just transform their polities in order to system- 
atically control economic activity and plunder natural-resource wealth; they also cultivate extensive networks of transnational actors and institutions to assist in camouflaging their financial flows and polishing their reputations. Although some of these relationships and activities remain hidden, a hallmark of contemporary kleptocracy lies in its public face and visibility. Unlike other illicit actors-such as narcocriminals and terrorists-who keep their extensive transnational ties in the shadows, kleptocrats tend to use the agents, services, and institutions of globalization not only to safeguard their assets, but also to maintain a high-profile status.

Key to this process is the work of professional intermediaries who blend ill-gotten gains together with legal financial flows and investments. The intermediaries hired by kleptocrats-including bankers, realestate brokers, accountants, lawyers, wealth managers, and public-relations agents - work to untether their clients' profiles from their original corrupt acts, recasting them as respected cosmopolitan businesspeople and philanthropists, often through the use of global-governance institutions. Frequently, this effort involves touting the putative prodemocratic and anticorruption credentials of kleptocratic actors.

Using these intermediaries, kleptocrats amplify their sway and enhance their security by building relationships with influencers and institutions abroad. These efforts have given birth to a "transnational uncivil society": While at home many kleptocrats crack down on civil society and its links to outside NGOs, funders, and media outlets, globally they foster a complex web of cross-border ties. ${ }^{2}$ Unfortunately, at present the global balance between transnational civil society and this darker counterpart appears to be tilting toward the latter.

\section{The New Kleptocracy}

The international aspect of kleptocracy is geared toward two principal objectives: the laundering of money and the laundering of reputations. Of course, neither kleptocracy nor kleptocratic networks are new. Accounts from the 1960s and 1970s relay the brutality of infamous kleptocrats-including Philippine president Ferdinand Marcos (1965-86), Haitian president Jean-Claude Duvalier (1971-86), and Zairean president Mobutu Sese Seko (1965-97)—who enriched themselves and their families while impoverishing their populations. We now also know that these same figures stashed billions of dollars in secret Swiss bank accounts. Yet two important features distinguish the current era of global kleptocracy from these forerunners.

First, a changing global situation has eroded the once-automatic primacy of geopolitics in the West's relations with kleptocrats. Throughout the Cold War, most foreign-policy makers accepted as a given that a country's geopolitical orientation trumped concerns about its domestic 
abuses, including authoritarianism, human-rights violations, and grand corruption. To ensure regime stability and allegiance, Western countries often channeled development aid to kleptocrats through international financial institutions such as the IMF and the World Bank. As U.S. president Ronald Reagan publicly commented in 1986 with regard to whether the United States should tolerate the authoritarian excesses of Marcos, "I don't know of any[thing] that's more important than the [military] bases on the Philippines." 3

Similarly, to safeguard French companies and strategic interests following formal decolonization in French Africa in 1960, elites in France established an elaborate system of postcolonial ties later dubbed "La Françafrique." These arrangements, which lasted over three decades, ensured that African autocrats would protect French interests in exchange for Paris allowing massive sums obtained through graft and kickbacks to pass through French banks, energy firms, and mining companies. ${ }^{4}$

The end of the Cold War not only lifted geopolitical pressure on the United States to support anti-Soviet client states, but also led to a fundamental shift in international attitudes toward corruption. Until the 1990s, the view that corruption was a necessary part of doing business in many developing countries was widespread; until 1998, for example, German companies could write off overseas bribes from corporate taxes. During the 1990s, however, the belief that corruption was in fact morally objectionable and harmful to domestic development spread rapidly. In 1995, the Berlin-based watchdog Transparency International issued its inaugural Corruption Perceptions Index, a survey that dared to name and shame those countries regarded by outside respondents as the most corrupt in the world.

A series of international treaties and agreements-including the the Inter-American Convention Against Corruption (1996), OECD AntiBribery Convention (1997), and the United Nations Convention Against Corruption (2003)_-solidified the new anticorruption norm. After the Cold War, the United States increased enforcement of its own Foreign Corrupt Practices Act (passed in 1977), and anticorruption efforts became a staple of its development-assistance programs. Finally, the international community came to publicly accept the principle that a kleptocrat's overseas assets, if proven to have resulted from ill-gotten gains, could be returned to their country of origin. ${ }^{5}$ Even in France, recent trials of African kleptocrats have signaled a growing rejection of the arrangements that previously sheltered the practices and proceeds of grand corruption.

The strengthening of the transparency norm in the post-Cold War era has transformed kleptocrats' approach to managing their wealth and their international reputations. No longer able to siphon money directly into foreign bank accounts or trade on their anticommunist credentials, kleptocrats have developed sophisticated global networks to launder their 
wealth and avoid international scrutiny. Central to these new networks are professional global intermediaries whose specialized services cater to high-net-worth international clients. In short, the West's institutions and brokers play a crucial role in facilitating transnational corruption.

\section{The Laundering of Money}

In the world of business and financial services, a whole industry servicing kleptocrats has emerged. From centers such as London and New York, it sprawls outward to a range of offshore jurisdictions and real-estate hotspots. Even when kleptocrats or their agents conduct business with non-Western partners - such as a Chinese state-owned enterprise- the money often flows through networks of companies arranged by Western financial-service providers, after which it may end up in the hidden accounts of rulers and their senior officials. Only recently have analysts begun to appreciate the global geography of money laundering.

Offshore finance: No institutional innovation has been more important for the kleptocrat than the untraceable shell company. The systematic use of shell companies is now commonplace for multinational firms that seek to minimize their tax liabilities in any given jurisdiction, as well as for wealthy individuals and kleptocrats who wish to operate in secrecy. Estimates of total wealth held in the offshore domain vary; economist Gabriel Zucman has estimated that 8 percent of global GDP is kept offshore, a figure that includes about 30 percent of African and 50 percent of Russian wealth. ${ }^{6}$

The release in 2016 of the Panama Papers, detailing the holdings of the Panamanian law firm Mossack Fonseca, revealed the industrial scale on which untraceable companies are used and the complexity of their nested structures. Together with recent scholarship, the Panama Papers have underscored a critical point: Despite popular conceptions that these shell companies are primarily registered in small tax havens in exotic locations, the most problematic jurisdictions are actually within the OECD. In a groundbreaking study, Michael Findley, Daniel Nielsen, and J.C. Sharman sent more than 7,400 solicitations to global corporateservice providers on behalf of fictitious clients with varying corruptionrisk profiles. Their investigation revealed that U.S. and U.K. shell-company providers were less likely to comply with the guidelines of the intergovernmental Financial Action Task Force on ascertaining company ownership than were so-called tax havens outside the OECD. In a claim echoed by later reports, the study identified company-service providers in Delaware, Nevada, and Wyoming, where incorporation services are a critical source of state revenues, as some of the most secretive in the world. ${ }^{7}$ As the global transparency regime gathers more steam, the United States seems to carve out more exceptions for itself. The trans- 
parency NGO Tax Justice Network ranked the United States below only Switzerland and Hong Kong on its 2015 Financial Secrecy Index. ${ }^{8}$

For many post-Soviet countries, offshoring and state-building have been intertwined, with regimes and ruling families amassing personal fortunes by channeling to foreign accounts rents from state assets such as commodities, foreign aid, and the sale of or profits from Soviet-era state-owned enterprises. In Kazakhstan, Mukhtar Ablyazov, a former government minister and head of the BTA bank, used more than a thousand shell companies to hide billions of dollars from the authoritiesa move that he claimed, with some justification, is used routinely by the Kazakhstani business and political elite. In Tajikistan, the profits of the state aluminum company and biggest national export-earner Talco went into shell companies registered in the British Virgin Islands and then served a variety of public and private purposes, among them retail purchases and business dealings for the benefit of members of the president's family. In Kyrgyzstan, businessmen linked to the son of President Kurmanbek Bakiyev (2005-10) ran Asia Universal Bank as a node in the offshore financial system, with billions of dollars flowing into anonymous company accounts, sometimes via correspondent relations with major international banks such as Standard Chartered and Raiffeisen. ${ }^{9}$

The global real-estate sinkhole: Once money is "cleaned" through networks of companies, its controllers may use it to advance both the social or political goals and the business interests of kleptocrats. Perhaps its most important destination is the global luxury real-estate market, where foreign nationals invest billions of dollars every year, mixing illicit and legal funds into assets protected by Western property laws. Of the ten leading locations that Christie's International Real Estate identified in its first annual report, issued in March 2013, on luxury housing around the world, nine were in the West; they included London, New York, and Paris. ${ }^{10}$ In all these markets, real-estate brokers facilitate transactions but bear very little responsibility for ascertaining the true identity of purchasers or the legality of their funds. In the United States, the National Association of Realtors has successfully lobbied for exemption from the Anti-Money Laundering (AML) disclosure requirements of the 2001 Patriot Act. ${ }^{11}$ In the United Kingdom, brokers have a duty to discern the identity of the seller, not the buyer, and the real-estate industry is largely self-regulated. With large commissions at stake, conflicts of interest abound. ${ }^{12}$ And throughout the world's highend markets, luxury purchases are commonly conducted via shell companies or trusts, adding more layers of secrecy.

The absence of academic research on the dynamics of the global market in luxury real estate is striking, but a series of high-profile investigative reports by journalists and NGOs in the United States and the United Kingdom appear to have spurred some action by U.S. regulators. A sting 
operation conducted by the makers of the U.K. Channel 4 documentary "From Russia with Cash" revealed that brokers, in order to facilitate transactions, appeared to willfully ignore red flags indicating that their clients were high corruption risks. ${ }^{13}$ After the publication of a high-profile New York Times exposé detailing the billionaires and shell companies that owned units in Manhattan's luxurious Time Warner Center, ${ }^{14}$ the U.S. Treasury Department's Financial Crimes Enforcement Network (FinCEN) rolled out a pilot program of Geographic Targeting Orders (GTOs) that mandated disclosure of the actual buyer in all-cash purchases above a certain threshold (\$3 million in Manhattan and \$1 million in Miami) during the purchase of title insurance. In the early stages of the program, FinCEN found that 30 percent of the beneficial owners or purchase representatives whom it identified had been the subjects of earlier suspicious-activities reports by U.S.-based financial institutions. ${ }^{15}$ Yet while the Treasury has now expanded the GTO program to ten markets, guidelines for real-estate professionals regarding AML issues remain in large part advisory rather than mandatory.

British regulators are only just beginning to grasp the scale of the problem. The National Crime Agency estimates that laundered money running through the United Kingdom may amount to a staggering $£ 90$ billion annually - much of it ending up in property. Between 2012 and 2016, the mutual legal-assistance requests (which are used to investigate money laundering) made to London by foreign governments more than doubled in number. A new law adopted in 2017 has given regulators greater powers to investigate unexplained wealth used in luxury realestate purchases. ${ }^{16}$ But sometimes it is activists rather than the authorities who turn up the lid on suspicious cases. The NGO Global Witness found that after fleeing to the United Kingdom from Kyrgyzstan in 2010, Maksim Bakiyev, the son of the ousted president, took up residence in a mansion in Surrey bought through an anonymous company. ${ }^{17}$ Other examples abound, with a politically connected Russian billionaire and a onetime minister in the Nigerian government among those believed to have purchased luxury apartments in the same London skyscraper, in which offshore companies control a quarter of the units. ${ }^{18}$

\section{The Laundering of Reputations}

Moving and investing money transnationally is the first imperative of the modern kleptocrat, but laundering one's reputation is also critical. In the cases mentioned above, Kazakhstan has hired companies to paint Ablyazov as a bad apple, Tajikistan has used its offshore accounts to fund lobbying in the U.S. Congress, and Asia Universal Bank has hired three former U.S. senators to serve on its board as a demonstration of stature and legitimacy. ${ }^{19}$

Reputation laundering involves minimizing or obscuring evidence of 
corruption and authoritarianism in the kleptocrat's home country and rebranding kleptocrats as engaged global citizens. Its murkier cousin is so-called "black PR," aimed at sullying the reputations of a kleptocrat's political rivals. Reputation laundering comprises a web of interrelated practices that go beyond the economic realm to encompass various social-networking and political techniques. These include securing the right for the kleptocrat to reside overseas, running an aggressive imagecrafting and public relations campaign, and using philanthropic activities to ensconce the kleptocrat in a web of transnational alliances.

Securing multiple citizenships: For kleptocrats and oligarchs, securing multiple rights of residency for themselves and their families provides a blanket of personal security, including access to the legal protections of a country where the rule of law is more reliable than at home. It also offers an exit option should their domestic political fortunes shift.

One common technique is for a kleptocrat to appoint relatives to the diplomatic corps, thereby ensuring these relatives the right to international travel as well as foreign residence and diplomatic immunity for crimes. In each of the Central Asian countries, close relatives of the president have routinely held high-level diplomatic positions. ${ }^{20}$ For example, Gulnara Karimova, the scandal-plagued daughter of Uzbekistan's former president Islam Karimov (1990-2016), served as a counselor to the country's UN mission in New York, ambassador to Spain, and permanent representative to the UN in Geneva. Ozoda Rahmon, the first daughter of the president of Tajikistan, has held senior posts in the Ministry of Foreign Affairs.

The right to live abroad is also increasingly available for purchase. Over the last decade or two, a global market in second citizenship and investor visas has emerged, allowing foreign nationals to acquire the right of residence in OECD countries and other potentially attractive states through perfectly legal mechanisms. All OECD countries have some type of investor-residence or visa program, while over half have introduced new programs to attract foreign capital in the wake of the global financial crisis. ${ }^{21}$

A new industry of international legal firms and second-citizenship specialists has sprung up to arrange these transactions. ${ }^{22}$ One of these firms, Henley and Partners, publishes and annually updates the "Global Residence and Citizenship Handbook," which it describes as "the international standard work in the field and a reliable guide for private clients, wealth management professionals and governments." ${ }^{23}$ The November 2017 International Residency and Citizenship Exhibition and Conference in Abu Dhabi targeted more than fifteen-thousand visitors, who learned about their options in small island nations such as Cyprus, Dominica, and St. Lucia as well as in such major states as Australia, Canada, and Spain. ${ }^{24}$ While this industry is not specifically targeted at 
kleptocrats, evidence suggests that the buyers of residency and citizenship are often wealthy nationals of states with high levels of corruption.

Data from individual country programs support this view. For example, figures released by the U.K. Migration Advisory Committee reveal that, of the 1,647 applications granted for residence under the Tier 1 investor program from its inception in 2008 to 2013, about a fourth went to Russian (433) and another quarter to Chinese nationals (419), with Egypt (46) and Kazakhstan (41) also among the top home countries of recipients. ${ }^{25}$ By 2015, according to Transparency International UK (TIUK), the combined share of these "golden visas" claimed by Chinese and Russian nationals had grown to 60 percent. Critics warned of lax oversight and a near complete lack of due diligence as to the origins of the funds invested through this program. A study conducted by TI-UK found that "it is highly likely that substantial amounts of corrupt wealth stolen from China and Russia have been laundered into the UK through the UK's Tier 1 Investor visa programme."26

The government of Cyprus also has established a golden-investor program, whose participants receive passports that-since Cyprus is an EU member-entitle holders to work and reside anywhere within the EU. According to investigative reporting by the Guardian, in 2016 alone more than four-hundred passports were granted under the program, which produced more than four-billion euros' worth of investment between its 2013 inception and mid-2017. Demand was particularly pronounced among individuals from Russia and Ukraine. The Guardian related that a leaked list of passport recipients included a former Russian parliamentarian, a billionaire Russian industrialist with reputed ties to President Vladimir Putin, and two Ukrainians who were then the largest shareholders in a bank later nationalized and embroiled in scandal. ${ }^{27}$

Similarly, in 2014, Malta (also an EU member) launched a passport program that requires applicants to hand over 650,000 euros to a national development fund and further invest 150,000 euros in government bonds. As of mid-2016, Maltese officials stated that the program had awarded close to seven-hundred passports to foreign nationals and yielded 200 million euros in revenue. ${ }^{28}$ EU lawmakers have raised concerns about both the Cypriot and the Maltese programs, with the European Parliament passing a resolution critical of the practice in 2014, but action from Brussels has not followed.

Public relations and global reputation management: Another critical component of "reputation laundering" for a kleptocrat is managing the international spotlight and influencing discussion. In the United States, formal lobbying for foreign clients is a well-established practice regulated under the Foreign Agents Registration Act (FARA) of 1938. To conduct political work on behalf of a foreign government, a U.S. actor or agent must formally register with the Department of Justice's 
Fara.gov database and detail the political activities performed. For the EU, registering for lobbying remains voluntary, while national regulations in European countries vary considerably - with nineteen states, according to a European watchdog, lacking firm legislation to regulate lobbying. ${ }^{29}$

But beyond these formal activities, oligarchs and kleptocrats have taken advantage of a plethora of informal channels to create dense networks of political allies, sympathetic commentators, and sites of influence. High-profile advisors and PR firms in the business of improving regimes' reputations overseas command hefty fees and offer a broad range of services. Former U.K. prime minister Tony Blair has been scrutinized for offering, through his consulting firm, political and strategic advice to Kazakhstan's President Nursultan Nazarbayev beginning in 2011 reportedly with an asking price of $£ 5.3$ million per year. The assistance provided by Blair and his firm included help in shaping the Kazakhstani government's response to the international criticism that followed its crackdown on protests by oil workers in the western town of Zhanaozen in December 2011, which resulted in fourteen confirmed deaths. ${ }^{30}$

In addition, firms under contract to kleptocrats can deploy against their opponents and other targets specialized services resembling those of state intelligence outfits. These offerings range from gathering compromising information to hacking into personal accounts and infiltrating inner circles. As a recent Financial Times investigative report into London's murky private-intelligence market found, "many firms have amassed expertise and tradecraft once monopolised by state agencies and put it at the service of tyrants, oligarchs and anyone else willing to pay." The report notes that Arcanum Global, a part of this intelligence-gathering and influence-shaping sector, peddled its services to Kazakhstan's rebellious oligarch Ablyazov while at the same time working for his foes in Astana. ${ }^{31}$

Public-relations firms also perform subtler forms of "reputation management," monitoring and shaping relevant open-source material, such as Wikipedia entries, or generating targeted social-media trends and campaigns on behalf of their clients. Although such work is legal, it can easily cross ethical lines. The recent collapse of the London-based PR firm Bell Pottinger was prompted by the release of a report detailing how the company, on behalf of business allies of scandal-plagued South African president Jacob Zuma, had waged a socially divisive campaign to deflect attention away from Zuma. The company's clients had also included Syrian president Bashar al-Assad's wife, as well as Belarus's dictator Alyaksandr Lukashenka. ${ }^{32}$ In certain cases, firms may even pressure journalists and publishers to refrain from publishing materials that might emphasize clients' unseemly activities in their home countries or otherwise damage their reputations.

Knowledge centers and policy institutes also make attractive targets for rulers interested in burnishing their images. In U.S. law, disclo- 
sure requirements for think tanks are much less stringent than those for formal lobbyists. A New York Times exposé on foreign funding of U.S. think tanks revealed that many ostensibly reputable institutions regularly fail to disclose the foreign origins of their project funding. ${ }^{33}$ In addition to their possible influence on U.S. foreign-policy thinking, such funds may deter knowledge centers from even addressing the potentially corrupt activities of their donors. In this way, these monies may work to normalize the activities of kleptocrats and keep investigations into their personal fortunes off the agenda. In a hard-hitting review of Ukrainian oligarchs' influence and lobbying activities in the United States, Taras Kuzio concludes that "buying . . . the services of politicians, consultants, lobbyists, think tanks and lawyers is only one part of a wider problem of reverse corruption from corrupt countries and authoritarian political leaders." 34

Even universities are now sites for potential influence campaigns. Though most prestigious universities do have committees to vet proposed foreign donations, there is no accepted international standard for this vetting. In most cases, the burden of proof is on those seeking to show that the monies offered are the proceeds of an illegal or nefarious act. In 2011, a series of scandals erupted around revelations of financial links between the London School of Economics (LSE) and the regime of former Libyan dictator Muammar al-Qadhafi. In March 2009, the autocrat's son Saif was found to have made a $£ 1.5$ million donation through his charity to LSE's Centre for Global Governance just months after LSE awarded him a doctorate. This "Libya links" scandal led to the resignation of LSE director Howard Davies and an internal inquiry into the university's due-diligence process.

Such cases also highlight the questionable standards of a due-diligence industry operating behind closed doors. When the Norwegian conglomerate Hydro did business with TML, one of the shell companies receiving the profits from the Tajikistani aluminum industry, due diligence conducted for Hydro on TML "revealed nothing that was considered harmful for the reputation of the owners." Yet a large amount of public evidence-much of it gathered in court cases to which Hydro had been a party — was available regarding corruption in Tajikistan's aluminum industry and the subordination of offshore companies such as TML to the government. ${ }^{35}$ In cases such as this, due diligence seems to offer nominal adherence to corporate regulations while providing plausible deniability to clients who may then chose to make or break a deal with a kleptocratic regime as they prefer. While looking for smoking-gun evidence of corruption, investigators ignore the questions that would arise under a balance-of-probability standard. No regional expert would have argued that there was a low probability of corruption in Tajikistan's aluminum industry. 
Philanthropy with a dual purpose? The professional guardians of kleptocrats' reputations often tout their clients' philanthropic activities. For kleptocrats, such activities represent not only an additional channel for laundering money, but also an opportunity to cultivate networks of allies in other governments, nonprofits, and international organizations - a web of relationships constituting what we call "transnational uncivil society."

Before her fall from power in 2013, Uzbekistan's Gulnara Karimova presided over Fund Forum, a charitable foundation that she used to sponsor pet projects and promote her image globally. The foundation entered into partnerships with respected institutions, including the Louvre $\mathrm{Mu}$ seum in Paris, the British Council, the Japanese International Cooperation Agency, and a breast-cancer charity. ${ }^{36}$ Much of its work involved organizing ostentatious cultural events for the elite of Uzbekistan, including the annual Style.uz fashion and art expo in Tashkent. Nonetheless, foreign states wishing to curry favor evidently found tempting the opportunity to partner with the then-powerful Karimova, who thereby bolstered her international credibility.

In 2008, the United Nations Educational, Scientific and Cultural Organization (UNESCO) agreed to establish a life-sciences research award funded by and bearing the name of Equatorial Guinea's president Teodoro Obiang (it was later renamed in a partial sop to critics). Most of Equatorial Guinea's citizens lack access to basic medical facilities, while its ruling family has been under investigation for offenses linked to grand corruption in the United States, Switzerland, France, and Spain; a French court found Vice-President Teodorin Obiang (Teodoro's son) guilty of embezzlement and money laundering in October 2017. ${ }^{37}$

Azerbaijan offers a striking example of how kleptocrats can blend financial and political tactics in targeted influence efforts. In September 2017, an investigative report by the Organized Crime and Corruption Reporting Project and the Guardian revealed that, between 2012 and 2014, the Azeri government had channeled \$2.9 billion in payments through the Estonian branch office of a Danish bank and four U.K.-registered shell companies whose beneficial owners were kept secret. Much of the cash went to a campaign aimed at winning over image-crafters, lobbyists, and European politicians engaged with the Caspian country, including at least one participant in election observation. This episode came in the wake of the so-called "caviar diplomacy" scandal of 2013, which revolved around revelations that the Azerbaijani government had provided cash payments, gifts, and luxury trips to members of the European Parliament. ${ }^{38}$

\section{What Is to Be Done?}

One of the ironies of everyday kleptocracy lies in the fact that kleptocrats, after perverting the law to acquire wealth in their home jurisdictions, rely on the law to protect that wealth in other jurisdictions. 
Yet this does not mean that upholding the rule of law requires Western officials to turn a blind eye to questionable activities by foreign despots. In fact, the contrary is true. Kleptocracy depends heavily on the partial and selective use of the law, the uneven implementation of rules to block tainted funds from abroad. Tightening laws in a few key areas and, above all, strengthening the enforcement of existing regulations could do a great deal to prevent Western legal and financial industries from further enabling kleptocracy.

Everyday kleptocracy thrives thanks to significant shortcomings in transparency and accountability requirements, including in states deemed to be among the least corrupt in the world. Plugging the holes in the global anti-money-laundering regime will require countries worldwide to establish national beneficial-ownership registries, with the end goal of creating a searchable global registry of companies. Firms that set up shell companies should also be mandated to establish, record, and report the true identities of their customers. These measures will also make regulation of the luxury-property market easier. For the real-estate industry, reporting should become mandatory in high-value sales rather than continue to depend on self-regulation-which, as in the financial sector, "stands in relation to regulation the way self-importance stands in relation to importance." 39

Governments have outsourced much of the work of financial surveillance to private-sector firms, especially banks. But in the absence of close supervision and credible sanctions for dereliction of duty, it is naïve to expect these intermediaries to pass up profitable opportunities to accept dubious clients. While U.S. federal and state regulators have increasingly imposed sizeable penalties on banks, they have largely continued to give a free pass to other institutions-from law firms to realestate agencies - that have shirked their due-diligence responsibilities.

Western governments can clip the wings of kleptocrats by imposing visa-denial regimes on those credibly accused of crimes related to grand corruption. The United States and Britain have instituted such regimes but applied them unevenly, and despite calls for coordinated action by the G-20, other countries have been reluctant to follow suit. ${ }^{40}$ Anticorruption efforts could also make greater use of the new system of worldwide automatic tax-information exchange instituted in connection with the OECD Common Reporting Standard. Finally, important allies in the struggle for accountability could be empowered by giving civil society groups and other private parties standing to take direct legal action (criminal and civil) against tainted wealth from abroad and the intermediaries who host it. This could be done through such legal provisions as the United States' Racketeering and Corruption Organizations (RICO) Act, constructive-trust provisions (allowing the repossession of illicit assets), and qui tam lawsuits (allowing whistleblowers to become a party). ${ }^{41}$

With regard to reputation laundering, we need coalitions of academic 
researchers, journalists, and civil society groups to conduct in-depth and innovative investigations. Such explorations could start close to home with a look into the funding received by think tanks and universities. Moreover, public institutions should be required to abide by transparency standards similar to those of the Foreign Agents Registration Act, with disclosure of all meetings taken and donations received. Finally, the private-intelligence and reputation-management industries should be subject to similar reporting standards. For deals above a certain threshold, due-diligence reports-products currently of doubtful provenance, yet potentially of great significance in countering corruption-should be published online with all sources anonymized.

Weak transparency regimes have allowed professional intermediaries to construct a mask of respectability for corrupt rulers and their cash. From academic research to the world of finance, opening up the deeds of corrupt foreign actors to public and regulatory scrutiny will help to prevent elites who trample on the rule of law at home from selectively invoking it to protect themselves abroad. Without such changes, Western states, particularly the United States and the United Kingdom, will see the rule of law and democratic norms corroded in their own societies as they play host to increasingly globalized and influential foreign kleptocrats.

\section{NOTES}

1. World Bank and United Nations Office on Drugs and Crime, "Stolen Asset Recovery (StAR) Initiative: Challenges, Opportunities, and Action Plan," World Bank, Washington D.C., June 2007; Global Witness, "Undue Diligence: How Banks Do Business with Corrupt Regimes," March 2009; U.S. Senate Permanent Subcommittee on Investigations, "Keeping Foreign Corruption out of the United States: Four Case Histories," 2010; Transparency International UK, "Closing Down the Safe Havens: Ending Impunity for Corrupt Individuals by Seizing and Recovering their Assets in the UK," December 2013.

2. Alexander Cooley and John Heathershaw, Dictators Without Borders: Power and Money in Central Asia (New Haven: Yale University Press, 2017), 47.

3. "The President's News Conference, February 11, 1986," Public Papers of Ronald Reagan, www.reaganlibrary.archives.gov/archives/speeches/1986/21186e.htm.

4. Pascal Airault and Jean-Pierre Bat, Françafrique: Opérations secrètes et affaires d'État (Paris: Tallandier, 2016).

5. J.C. Sharman, The Despot's Guide to Wealth Management: On the International Campaign Against Grand Corruption (Ithaca: Cornell University Press, 2017).

6. Gabriel Zucman, The Hidden Wealth of Nations: The Scourge of Tax Havens, trans. Teresa Lavender Fagan (Chicago: University of Chicago Press, 2015).

7. Bastian Obermayer and Frederik Obermaier, The Panama Papers: Breaking the Story of How the Rich and Powerful Hide Their Money (London: Oneworld, 2016); Michael G. Findley, Daniel L. Nielson, and J.C. Sharman, Global Shell Games: Experiments in Transnational Relations, Crime, and Terrorism (New York: Cambridge University Press, 
2014); Casey Michel, “The United States' Problem with Financial Secrecy: How It Undermines U.S. Foreign Policy," Foreign Affairs, 20 September 2017.

8. "Financial Secrecy Index," Tax Justice Network, www.financialsecrecyindex.com.

9. Cooley and Heathershaw, Dictators Without Borders.

10. Christie's International Real Estate, "Luxury Defined: An Insight into the Luxury Residential Property Market," March 2013, www.christiesrealestate.com/ resources/v_1_1_20_1/siteresources/my\%20folder/external-files/cire_whitepaper $\operatorname{mar} 2013 . p d \bar{f}, 1 \overline{7}$.

11. Transparency International, "Doors Wide Open: Corruption and Real Estate in Four Key Markets," 2017.

12. Transparency International UK, "Faulty Towers: Understanding the Impact of Overseas Corruption on the London Property Market," March 2017.

13. Randeep Ramesh, "London Estate Agents Caught on Camera Dealing with 'Corrupt' Russian Buyer," Guardian, 7 July 2015.

14. Louise Story and Stephanie Saul, "Stream of Foreign Wealth Flows to Elite New York Real Estate," New York Times, 7 February 2015.

15. "FinCEN Renews Real Estate 'Geographic Targeting Orders' to Identify High-End Cash Buyers in Six Major Metropolitan Areas," United States Department of the Treasury Financial Crimes Enforcement Network, 23 February 2017, www.fincen.gov/news/newsreleases/fincen-renews-real-estate-geographic-targeting-orders-identify-high-end-cash.

16. Caroline Binham "Foreign Money Laundering Inquiries to UK Leap 12\%," Financial Times, 11 June 2017.

17. Global Witness, "Blood Red Carpet,” March 2015.

18. Robert Booth and Helena Bengtsson,"The London Skyscraper That Is a Stark Symbol of the Housing Crisis," Guardian, 24 May 2016.

19. Cooley and Heathershaw, Dictators Without Borders.

20. Cooley and Heathershaw, Dictators Without Borders.

21. Matthew Valencia, "Citizens of Anywhere," 1843, 2 October 2017; Alexander Cooley and J.C. Sharman, "Transnational Corruption and the Globalized Individual," Perspectives on Politics 15 (September 2017): 732-53.

22. Kristin Surak, "Global Citizenship 2.0: The Growth of Citizenship by Investment Programs," Investment Migration Working Paper no. 3 (Geneva: Investment Migration Council, 2016), http://investmentmigration.org/download/global-citizenship-2-0-growthcitizenship-investment-programs.

23. "Citizenship by Investment," Henley and Partners, www.henleyglobal.com/citizenship-planning.

24. See the exposition's website at www.citizenshipexpo.com.

25. "Tier 1 (Investor) Route: Investment Thresholds and Economic Benefits," Migration Advisory Committee, London, February 2014, 22.

26. "Gold Rush: Investment Visas and Corrupt Capital Flows into the UK," Transparency International UK, October 2015. 
27. Sara Farolfi, David Pegg, and Stelios Orphanides, "Cyprus 'Selling' EU Citizenship to Super Rich of Russia and Ukraine," Guardian, 17 September 2017; Sara Farolfi, David Pegg, and Stelios Orphanides, "The Billionaires Investing in Cyprus in Exchange for EU Passports," Guardian, 17 September 2017.

28. Harry Cooper, "Malta Slammed for Cash-for-Passport Program," Politico (Europe), 17 August 2016.

29. Corporate Europe Observatory, "Spin Doctors to the Autocrats: How European PR Firms Whitewash Repressive Regimes," 2015, 8.

30. Robert Mendick, “Tony Blair’s $£ 5$ m Deal to Advise Kazakh Dictator,” Telegraph, 23 April 2016; Casey Michel, "Details of Tony Blair's Dealings with Kazakhstan Leaked,' Diplomat, 25 April 2016.

31. Tom Burgis, "Spies, Lies and the Oligarch: Inside London's Booming Secrets Industry," Financial Times, 28 September 2017.

32. Liz Alderman, "Bell Pottinger, British P.R. Firm for Questionable Clients, Collapses," New York Times, 12 September 2017.

33. Eric Lipton, Brooke Williams, and Nicholas Confessore, "Foreign Powers Buy Influence at Think Tanks," New York Times, 6 September 2014.

34. Taras Kuzio, "Ukrainian Kleptocrats and America's Real-Life House of Cards: Corruption, Lobbyism and the Rule of Law," Communist and Post-Communist Studies 50 (March 2017): 38.

35. Cooley and Heathershaw, Dictators Without Borders, 109.

36. "Uzbekistan: Karimova's Philanthropic Activities Raise Concern," Eurasianet, 26 April 2012,www.eurasianet.org/node/65319.

37. "UNESCO: Disappointing Vote on Obiang Prize," Human Rights Watch, 9 March 2012, www.hrw.org/news/2012/03/09/unesco-disappointing-vote-obiang-prize; "UNESCO Equatorial Guinea Obiang Nguema prize 'shameful,"” BBC, 16 July 2012; Angelique Chrisafis, "Son of Equatorial Guinea's President Is Convicted of Corruption in France," Guardian, 27 October 2017.

38. Luke Harding, Caelainn Barr, and Dina Nagapetyants, "Everything You Need to Know About the Azerbaijani Laundromat," Guardian, 4 September 2017; European Stability Initiative, "Caviar Diplomacy: How Azerbaijan Silenced the Council of Europe, Part 1," 24 May 2012; Gerald Knaus, "Europe and Azerbaijan: The End of Shame," Journal of Democracy 26 (July 2015): 5-18.

39. Willem Buiter quoted in Martin Wolf, "Why Financial Regulation Is Both Difficult and Essential," Financial Times, 15 April 2008.

40. "Denial of Entry to Corrupt Officials," Transparency International, G20 Position Paper, May 2014.

41. On such options see Open Society Foundations, "Legal Remedies for Grand Corruption," October 2016, www.opensocietyfoundations.org/publications/legal-remediesgrand-corruption. 